\title{
Mild Salinity Stimulates Biochemical Activities and Metabolites Associated with Anticancer Activities in Black Horehound (Ballota nigra L.)
}

\author{
Mehdi Younessi-Hamzekhanlu ${ }^{1,+}{ }^{(}$, Zahra Dibazarnia ${ }^{1,+}$, Shahin Oustan ${ }^{2}$, Teniyah Vinson ${ }^{3}$, Ramesh Katam ${ }^{3, *}$ \\ and Nasser Mahna ${ }^{1, * \mathbb{D}}$ \\ 1 Department of Horticultural Sciences, University of Tabriz, Tabriz 51666, Iran; \\ mehdiyounessi377@gmail.com (M.Y.-H.); zdiba19@yahoo.com (Z.D.) \\ 2 Department of Soil Sciences, University of Tabriz, Tabriz 51666, Iran; oustan@hotmail.com \\ 3 Department of Biological Sciences, Florida A\&M University, Tallahassee, FL 32307, USA; \\ vinson.teniyah@famu.edu \\ * Correspondence: ramesh.katam@famu.edu (R.K.); mahna@tabrizu.ac.ir (N.M.) \\ + These authors contributed equally to this work.
}

check for

updates

Citation: Younessi-Hamzekhanlu, M.; Dibazarnia, Z.; Oustan, S.; Vinson, T.; Katam, R.; Mahna, N. Mild Salinity Stimulates Biochemical Activities and Metabolites Associated with Anticancer Activities in Black Horehound (Ballota nigra L.). Agronomy 2021, 11, 2538. https:// doi.org/10.3390/agronomy11122538

Academic Editor: Matteo Caser

Received: 2 October 2021

Accepted: 6 December 2021

Published: 14 December 2021

Publisher's Note: MDPI stays neutral with regard to jurisdictional claims in published maps and institutional affiliations.

Copyright: (c) 2021 by the authors. Licensee MDPI, Basel, Switzerland. This article is an open access article distributed under the terms and conditions of the Creative Commons Attribution (CC BY) license (https:/ / creativecommons.org/licenses/by/ $4.0 /)$.
Abstract: Black horehound (Ballota nigra L.) is one of the most important medicinal plants, as a rich source of health-promoting essential oils and metabolites. Salinity stress affects plant development and alters antioxidant activity and plant metabolite composition. The present research aimed to study the effect of salinity on physiological and biochemical changes and metabolites of B. nigra under greenhouse and in vitro culture conditions. The plants were treated with different concentrations of $\mathrm{NaCl}(25,50,75,100 \mathrm{mM})$, and morphological characteristics of the plant were measured. The growth-related traits and soil plant analysis development (SPAD) were decreased both in vivo and in vitro. Additionally, increased salt concentration negatively affected the cell membrane integrity. The total phenolic content and flavonoids of plants growing in the greenhouse increased by $21 \%$ at $50 \mathrm{mM}$ of $\mathrm{NaCl}$, but the amounts decreased significantly at higher stress levels $(100 \mathrm{mM}$ of $\mathrm{NaCl})$. Antioxidant activity was also measured. Among the $\mathrm{NaCl}$ treatments, the most increased DPPH scavenging activities $\left(\mathrm{IC}_{50}\right)$ under greenhouse and in vitro conditions were detected at mild salinity stress, but the activity significantly decreased in higher salinity treatments (i.e., 75 and $100 \mathrm{mM}$ ). In general, with increasing the salinity level to $75 \mathrm{mM}$, the activities of CAT and APX were significantly upregulated in both greenhouse and in vitro culture conditions. A correlation between total phenolics and flavonoids contents as well as antioxidant activity was obtained. Salinity level caused a shift in the metabolite expression. Mild salinity stress elevated the metabolites involved in anticancer and anti-inflammatory activities, such as $\beta$-ionone and caryophyllene oxide. However, the higher salt stress resulted in a significant reduction in their expression. Differential expression of metabolites to various levels of salt stress can be further exploited for the in vitro biosynthesis of metabolites.

Keywords: antioxidants; Ballota nigra; essential oils; salinity

\section{Introduction}

Soil salinity is an important abiotic stress factor that limits plant growth, affecting agricultural production and crop sustainability. To date, nearly $20 \%$ of the world's agricultural land is under saline conditions; thus, its impact on severe losses is estimated to be USD 12 billion each year [1]. Soil salinity has increased over time and is more prevalent in arid and semi-arid regions where frequent drought occurs, perturbing high evaporation in plants [2]. It is predicted that soil salinity will increase exponentially in the wake of climate change [3]. During this process, various salts accumulate in the surface layers of the soil, thus exposing the plants to secondary drought stress [4].

Ballota nigra L. is a perennial medicinal plant belonging to the mint family, Lamiaceae. It is widely distributed in temperate and subtropical regions in Europe and the Middle 
East. The plant inhabits waste-filled environments and roadsides in human settlements, as well as weedy places and cultivated grounds [5]. Species of Ballota L. are traditionally used for cardiovascular diseases and the inflammation of the respiratory tract. Other medicinal purposes include treating nausea, vomiting, nervous dyspepsia, and producing mildly astringent sedatives, and antimicrobial agents [6]. The majority of the global population relies on herbal medicine supplements [7,8]. However, the quality and quantity of these herbal metabolites totally depend on environmental conditions such as soil salinity and drought.

High salt concentrations in the soil can cause detrimental effects on plant growth and development, germination, yield, nutrient uptake, photosynthesis, quality, and quantity of primary and secondary metabolites. Salt stress affects medicinal plants through different physiological stages, including seed germination, seedling growth by blocking the mobilization of reserve foods, injuring hypocotyls, and suspending cell division $[9,10]$. A similar impact on morphological characteristics such as leaf number, leaf area, and biomass was observed in several medicinal plants [11,12].

Salinity stress leads to oxidative stress in plants and an increase in reactive oxygen species (ROS). These oxygen-derived radicals reduce target precursor biomolecules essential for metabolic processes and inhibit their synthesis [13]. In addition, ROS attack vital cell macromolecules such as nucleic acids, proteins, and lipids and cause mutations in the structure of DNA, alter the nature of proteins, and damage membranes [14-16]. Proline content increases as a stress osmolyte increases under salinity stress in plants such as peppermint, sage, and summer savory [17]. Salinity stress affects the production of secondary metabolites and essential oils in medicinal plants [18]. The composition of essential oil, phenolic compounds, proline, and photosynthetic pigments is differentially expressed in the plants grown under salinity conditions [19]. The levels of terpenoids such as menthol in mint, carvacrol in coriander, 1,8-cineole in sage, and linalool in basil increased with increasing salinity [20]. In contrast, metabolites such as gamma-terpinene in coriander, p-cymen in marjoram, and eugenol were reduced in basil [21,22].

Due to the significance of fragrant species in terms of medicine, understanding the mechanisms underlying salt tolerance in medicinal plants has gained importance, with relevance to the production of essential oils and other secondary metabolites. Developing salt-tolerant medicinal plants leads to increased raw materials for drugs, flavors, fragrances, and spices. To increase the production of a medicinally essential compound in plants, it is necessary to understand the distribution of the metabolites in the plants in response to various levels of salt stress. Therefore, this study was carried out to determine the effects of sodium chloride on morphological, physiological, and biochemical characteristics, and the metabolites of B. nigra.

\section{Results and Discussion}

\subsection{Soil Salinity Inhibited Plant Growth and Yield}

Analysis of variance showed that salinity has a significant effect $(p<0.01)$ on all growth-related traits in vivo and in vitro (Table 1). Plant morphological traits such as leaf number, leaf area, root and shoot length, fresh and dry weights of both root and shoot tissues, soil plant analysis development (SPAD), and branch numbers were significantly reduced by $\mathrm{NaCl}$ ( $25 \mathrm{mM}$ to $100 \mathrm{mM}$ )-induced salt treatment (Table 2). 
Table 1. ANOVA of salinity stress effect on growth parameter measured in the greenhouse and in vitro.

\begin{tabular}{|c|c|c|c|c|c|c|c|c|c|c|c|c|c|c|}
\hline \multirow[b]{2}{*}{ S.V } & \multirow[b]{2}{*}{ d.f } & \multicolumn{9}{|c|}{ Mean of Squares (Greenhouse) } & \multicolumn{4}{|c|}{ Mean of Squares } \\
\hline & & LN & LA & RL & RFW & RDW & SHL & SFW & SDW & SPAD & d.f & LN & SHE & NB \\
\hline Repeat & 2 & 45.3 & 1431.9 & 0.3 & 40.7 & 0.8 & 0.1 & 158.5 & 7.05 & 9.2 & - & - & - & - \\
\hline Salinity & 4 & $52.7 * *$ & $6690.9^{* *}$ & $20.4^{* *}$ & $519.8^{* *}$ & $6.0 * *$ & $20.4^{* *}$ & $47.0 * *$ & $12.2 * *$ & $106.2^{* *}$ & 4 & $729.1^{* *}$ & $4.5^{* *}$ & $19.7^{* *}$ \\
\hline Error & 8 & 21.0 & 257.1 & 0.4 & 8.8 & 0.2 & 0.4 & 24.32 & 0.7 & 1.4 & 10 & 4.3 & 0.3 & 0.6 \\
\hline C.V & & 10.5 & 3.8 & 2.1 & 8.1 & 5.7 & 2.1 & 8.2 & 6.9 & 3.7 & & 10.2 & 18.7 & 20.6 \\
\hline
\end{tabular}

LN: leaf number, LA: leaf area, RL: root length, RFW: root fresh weight, RDW: root dry weight, SHL: shoot length, SFW: shoot fresh weight, SDW: shoot dry weight, SPAD: soil plant analysis development, NB: number of branches. ${ }^{* *}$ shows a significant difference at $5 \%$ significance level $(p \leq 0.05)$.

Table 2. Effect of salinity stress on physiological parameters measured in the greenhouse and in vitro.

\begin{tabular}{|c|c|c|c|c|c|c|}
\hline & & & $\mathrm{NaCl}(\mathrm{mM})$ & & & \\
\hline Condition & Characteristics & $\mathbf{0}$ & 25 & 50 & 75 & 100 \\
\hline \multirow{8}{*}{ 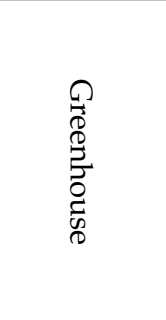 } & Leaf Number & $66.5 \pm 2.2 \mathrm{a}$ & $48.3 \pm 2.1 \mathrm{~b}$ & $37.2 \pm 1.2 c$ & $33 \pm 1.2 c$ & $32 \pm 0.8 \mathrm{c}$ \\
\hline & Leaf Area & $476.3 \pm 7.2 \mathrm{a}$ & $446 \pm 14.5 \mathrm{a}$ & $396.5 \pm 8.5 b$ & $372.5 \pm 10.2 c$ & $351.2 \pm 15.6 \mathrm{c}$ \\
\hline & Root Length & $33.2 \pm 1.2 \mathrm{a}$ & $33.6 \pm 1.5 \mathrm{a}$ & $29.3 \pm 0.8 \mathrm{~b}$ & $28.3 \pm 0.4 b$ & $28.2 \pm 0.3 \mathrm{~b}$ \\
\hline & Root Fresh Weight & $52.9 \pm 1.9 \mathrm{a}$ & $46.5 \pm 1.6 \mathrm{~b}$ & $34.8 \pm 2.5 c$ & $27.7 \pm 1.2 \mathrm{~d}$ & $20.8 \pm 1.1 \mathrm{e}$ \\
\hline & Root Dry Weight & $9.2 \pm 0.4 \mathrm{a}$ & $8.1 \pm 0.3 b$ & $6.6 \pm 0.4 \mathrm{c}$ & $6.2 \pm 0.4 c$ & $5.9 \pm 0.5 c$ \\
\hline & Shoot Length & $31.5 \pm 0.5 \mathrm{a}$ & $28.6 \pm 0.6 \mathrm{~b}$ & $24.2 \pm 0.6 \mathrm{c}$ & $23.2 \pm 0.4 \mathrm{c}$ & $21.3 \pm 0.3 \mathrm{~d}$ \\
\hline & Shoot Fresh Weight & 78. $\pm 1.1 \mathrm{a}$ & $64.2 \pm 3.6 b$ & $60.8 \pm 3.5 b c$ & $49.5 \pm 2.2 \mathrm{~cd}$ & $48 \pm 2.8 \mathrm{~d}$ \\
\hline & Shoot dry Weight & $15.2 \pm 1.5 \mathrm{a}$ & $12.9 \pm 1.4 b$ & $12.2 \pm 1.8 \mathrm{bc}$ & $11.2 \pm 1.4 \mathrm{~cd}$ & $9.8 \pm 1.3 \mathrm{~d}$ \\
\hline \multirow{4}{*}{ 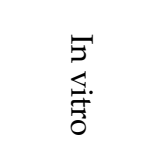 } & SPAD & $40.4 \pm 1.5 \mathrm{a}$ & $35.3 \pm 0.3 b$ & $33.5 \pm 0.3 b$ & $29.3 \pm 0.2 c$ & $24.7 \pm 1.2 \mathrm{~d}$ \\
\hline & Leaf Number & $45 \pm 0.6 \mathrm{a}$ & $23.6 \pm 1.1 b$ & $18 \pm 1.2 \mathrm{c}$ & $12 \pm 1.1 \mathrm{~d}$ & $3.7 \pm 0.7 \mathrm{e}$ \\
\hline & Shoot Length & $4.6 \pm 0.3 \mathrm{a}$ & $3.6 \pm 0.6 \mathrm{ab}$ & $2.7 \pm 0.5 \mathrm{bc}$ & $2.5 \pm 0.4 \mathrm{c}$ & $1.4 \pm 0.5 \mathrm{~d}$ \\
\hline & Number of branches & $7.8 \pm 0.7 \mathrm{a}$ & $4 \pm 0.5 \mathrm{~b}$ & $3 \pm 0.5 \mathrm{~b}$ & $3 \pm 0.5 \mathrm{~b}$ & $1 \pm 0.3 \mathrm{~d}$ \\
\hline
\end{tabular}

Means along with the same letter are not significantly different at $5 \%$ significance level $(p \leq 0.05)$.

Leaf area and number decreased after the plant was exposed to a higher concentration of $\mathrm{NaCl}$ solution. Plants with reduced leaf area exhibit a low evaporation rate and prevent water loss, resulting in a reduction in photosynthetic machinery [23]. Exposure to higher $\mathrm{NaCl}$ levels caused severe damage to photosynthetic tissues and reduced leaf gas exchange due to the ion concentration in leaf tissues [24]. Overall, impaired absorption of important ions and elements such as calcium and nitrogen and closed stomata to prevent water loss reduce water uptake from the soil, affecting the plant growth $[25,26]$. Previous results have shown that the shoot length fresh weight of $B$. nigra decreases significantly due to increasing salt concentration [27].

SPAD value was reduced by increasing the $\mathrm{NaCl}$ concentration (Table 2). Reduction in SPAD value following photosynthetic pigments under salt stress leads to a reduction in the catalytic activity of the aminolevulinic acid synthase enzyme. This, in turn, catalyzes the production of 5-aminolevulinic acid, a key precursor in the chlorophyll pigment biosynthesis pathway [28]. A similar reduction in the growth indices of medicinal plants has been earlier reported in basil, Salvia spp., Carthamus, and Dracocephalum [29].

\subsection{Effect of Salinity on Cell Membrane Integrity}

The cell membrane stability was severed in the plants treated with higher saline conditions. The results show that $\mathrm{NaCl}$ concentration at $50 \mathrm{mM}$ and above result in an increase in electrolyte leakage compared to the in vivo grown control plants (Figure 1; Table 3). Due to their high energy and reactivity, these ions damage many cellular compounds such as fats, proteins, carbohydrates, and nucleic acids, and by altering membrane structure, causing electrolyte leakage $[30,31]$. Higher salt concentrations cause damage to the plasma membrane through the decline of the $\mathrm{K}^{+} / \mathrm{Na}^{+}$ratio and the production of reactive oxygen species, such as superoxide radicals, hydrogen peroxide, and hydroxyl radicals [32]. 


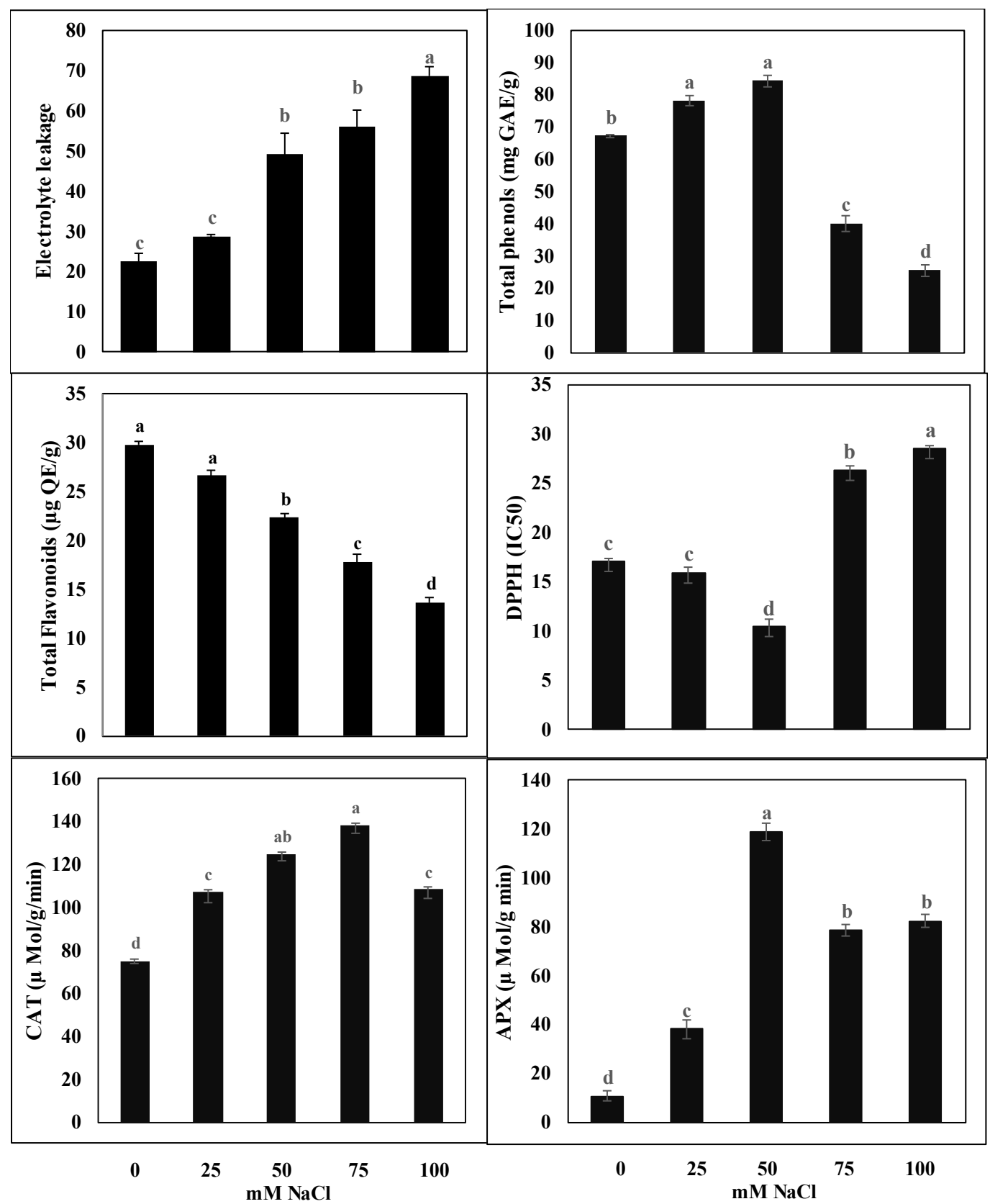

Figure 1. The effect of salinity stress on physiological and biochemical parameters measured in the greenhouse. Means along with the same letter are not significantly different at $5 \%$ significance level $(p \leq 0.05)$.

Table 3. ANOVA of salinity stress effect on physiological parameters measured in the greenhouse and in vitro.

\begin{tabular}{|c|c|c|c|c|c|c|c|c|}
\hline \multicolumn{9}{|c|}{ Mean of Squares } \\
\hline \multirow{5}{*}{ 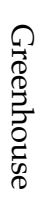 } & Source of variation & d.f & $\mathrm{TPh}$ & Flv & DPP & APX & CAT & EL \\
\hline & Repeat & 2 & 4.5 & 0.2 & 0.5 & 2391.3 & 0.8 & 4.63 \\
\hline & Salinity & 4 & $1916.5^{* *}$ & $126.5^{* *}$ & $171.2^{* *}$ & $132,662.0^{* *}$ & $1685.1^{* *}$ & $1104.0^{* *}$ \\
\hline & Error & 8 & 28.7 & 27.8 & 0.6 & 4178.9 & 335.3 & 54.8 \\
\hline & C.V\% & & 9.1 & 4.1 & 4.1 & 19.6 & 16.5 & 16.4 \\
\hline
\end{tabular}


Table 3. Cont.

\begin{tabular}{|c|c|c|c|c|c|c|c|c|}
\hline \multicolumn{9}{|c|}{ Mean of Squares } \\
\hline$\xi$ & Salinity & 4 & $563.6 *$ & $20.7^{* *}$ & $245.9 * *$ & $1965.1^{* *}$ & $284.4^{* *}$ & - \\
\hline$\leftrightarrows$. & Error & 8 & 119.6 & 2.8 & 5.6 & 63.0 & 46.9 & - \\
\hline Eే & C.V & & 9.3 & 11.6 & 10 & 12.5 & 25.8 & - \\
\hline
\end{tabular}

${ }^{*}$ and ${ }^{* *}$ show a significant difference at $1 \%(p \leq 0.01)$ and $5 \%$ significance level $(p \leq 0.05)$, respectively.

\subsection{Effect of Salinity on Total Phenols, Flavonoids, and Antioxidant Enzyme Activities}

Plant secondary metabolites such as phenol and total flavonoids have a strong potential for scavenging free radicals. These compounds act as electron donors and may neutralize unwanted reactions caused by free radicals in living organisms [33]. The presence of total phenolic compounds often correlates to the antioxidant activity of plant products. In this study, the total phenol contents were initially found in higher amounts in vitro cultures than in vivo. These results are similar to earlier reports that observed in vitro cultures of $B$. nigra [34]. Total phenol contents increased by $20 \%$ in response to moderate salt stress $(50 \mathrm{mM}$ of $\mathrm{NaCl})$ and started declining at higher salinity levels (75 and $100 \mathrm{mM}$ of $\mathrm{NaCl}$ ) in both in vivo and in vitro plants (Figures 1 and 2). Peppermint and rosemary extract has shown high antioxidant activity, which is directly related to the higher phenolic content of the plants [35]. Greenhouse-grown plants showed higher concentrations of total flavonoids compared to that of plants in vitro. However, their values significantly reduced in response to high salinity treatments.

On the contrary, the total flavonoids increased in response to $\mathrm{NaCl}$ treatments in vitro. Earlier studies showed a reduction in total phenol and flavonoid contents due to salt stress [36]. In general, the number of flavonoids in in vitro decreases compared to in vivo conditions; however, an acceptable number of these compounds is still produced in in vitro grown plants, suggesting in vitro cultures' potential for secondary metabolite production.

\subsection{Antioxidant Activity}

DPPH Radical scavenging activity: Free radical scavenging activity (DPPH) at IC50 was measured to assess the antioxidant capacity, representing the amount of B. nigra methanolic extract that can remove $50 \%$ of the DPPH radical in the environment. Among the $\mathrm{NaCl}$ treatments, the highest DPPH scavenging activity (IC50) in in vivo and in vitro conditions was detected in $50 \mathrm{mM}$ and $25 \mathrm{mM}$ concentrations, respectively (Figures 1 and 2). However, under in vitro conditions, treatments with 25 and $50 \mathrm{mM}$ of $\mathrm{NaCl}$ did not show a significant difference. The strongest DPPH scavenging activity (IC50) was observed (both in vivo and in vitro grown plants) at concentrations of 25 and $50 \mathrm{mM}$ of $\mathrm{NaCl}$, in which the number of phenolic and flavonoid compounds as antioxidant compounds was at a maximum (Figures 1 and 2).

Catalase and Ascorbate peroxidase enzyme assay: Catalase (CAT) and ascorbate peroxidase (APX) enzymes are the important antioxidants, as they improve plant defense systems to deal with abiotic stresses. These enzymes can directly convert hydrogen peroxide to water and oxygen and completely eliminate the toxicity of this oxygen-free radical [37]. Both APX and CAT are enzymatic components of antioxidant machinery with different affinities for hydrogen peroxide, wherein APX is responsible for fine-tuning reactive oxygen species for signaling and is a more efficient scavenger of $\mathrm{H}_{2} \mathrm{O}_{2}$, while CAT removes excess ROS under stress [38].

Our results indicate that $\mathrm{CAT}$ levels were higher in vivo than in vitro. The CAT activity increased up to $75 \mathrm{mM}$ in vivo, while their levels increased up to $50 \mathrm{mM}$ in vitro. It should be noted that the increase in vitro was higher $(65 \%)$ than in vivo $(45 \%)$ with respect to the control. APX was found in similar levels both in vivo and in vitro, and their levels were elevated to moderate levels of salinity stress (50 and $75 \mathrm{mM}$ of $\mathrm{NaCl}$, respectively) under both growth environments. $\mathrm{NaCl}$ at $100 \mathrm{mM}$ was detrimental for both the enzymes, as the activity of both enzymes reduced significantly at this higher salt stress. 


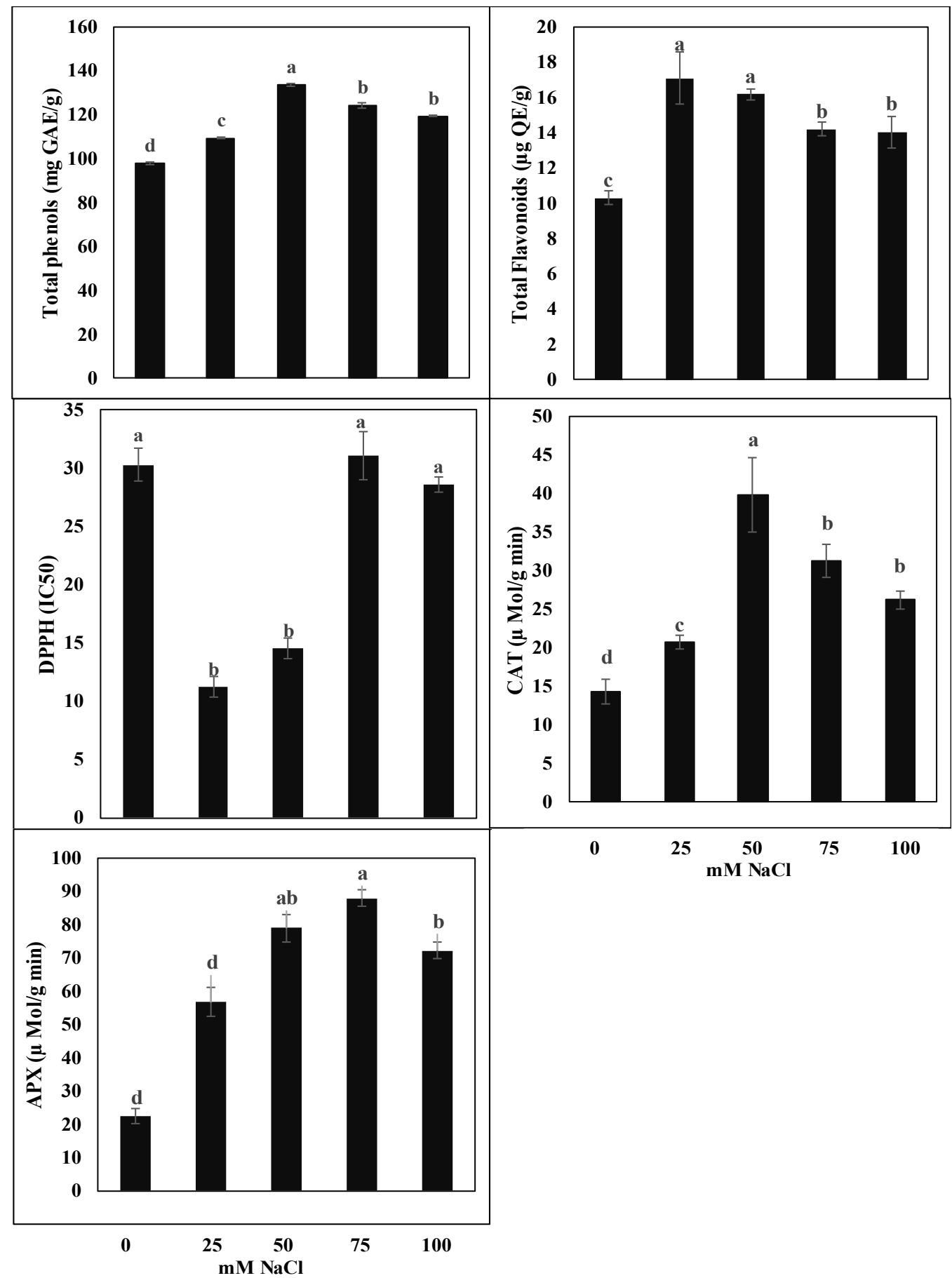

Figure 2. The effect of salinity stress on physiological and biochemical parameters measured in vitro. Means along with the same letter are not significantly different at $5 \%$ significance level $(p \leq 0.05)$.

In this experiment, the high amounts of APX in both in vivo and in vitro cultures suggest its role in regulating $\mathrm{ROS}$ for signaling under high-salt stress conditions $(\mathrm{NaCl}$ $>75 \mathrm{mM}$ ). APX is widely spread in cell organelles and detoxifies $\mathrm{H}_{2} \mathrm{O}_{2}$ in response to environmental stresses [39]. Several transcription factors are reported to regulate APX genes and improve plant tolerance against waterlogging stress [40]. APX is shown to increase in salt-tolerant cultivars, while it significantly diminishes in salt-susceptible cultivars of potato [41]. The observed enzyme (CAT and APX) values in response to $\mathrm{NaCl}$ stress in our studies were higher than some of the corresponding published data obtained in salt-tolerant cultivars when compared to susceptible potatoes. The decrease in the activity level of these 
enzymes at a high salt concentration $(100 \mathrm{mM})$ may be due to the increase in compounds such as hydrogen peroxide, which indicates that this level of salinity stress is beyond the tolerance of the $B$. nigra plant. In a higher salinity environment, the plant will not be able to modulate the oxidative stress caused by ROS, and consequently, electrolyte leakage, membrane disintegration, and photosynthetic pigment depredation will be intensified at this stress level [42].

The antioxidant enzymes work in conjunction to alleviate the damaging effects of ROS and develop tolerance to stress. However, the signaling and regulation of ROS in response salt stress are still not clearly understood. The expression and activities of antioxidant enzymes are controlled both directly and indirectly at multiple levels with the involvement of ubiquitous secondary messengers (ROS, RNS, and $\mathrm{Ca}^{2+}$ ), phosphorylation, redox-dependent post-translational modifications, and transcript factors [43].

ANOVA results show that total phenol and flavonoid content, DPPH (IC50) activity, APX, and CAT activity are significantly affected $(p<0.01)$ by $\mathrm{NaCl}$ stress in vivo and in vitro (Table 3). The first two principal components, PC1, and PC2, explain 83.6 and 12.3\% of the whole variance, respectively (Table 4). According to the eigenvectors of all variables in every two principal components, the correlation between the variables can be deduced from the biplot (Figure 3). The correlation of CAT and APX enzymes was positive but negative for total phenol content and DDPH (IC50), respectively. Based on the direction of the variables, vectors, and treatment points, it is inferred that the activity of two enzymes and the total phenol content (TPC) reached their maximum value at $50 \mathrm{mM}$ of $\mathrm{NaCl}$.

On the other hand, DPPH scavenging activity (IC50) and membrane integrity (electrolyte leakage) significantly decrease in higher salinity treatments (i.e., 75 and $100 \mathrm{mM}$ ). Overall, our findings corroborate the results obtained by mean comparison analysis. The minor change observed is only due to two components, which, while unable to entirely explain the variability, did explain a large portion of it ( $95.9 \%$ of the whole variation).

Table 4. PCA is based on the variables measured in greenhouse under different $\mathrm{NaCl}$ treatments.

\begin{tabular}{|c|c|c|}
\hline \multirow[t]{2}{*}{ Variables } & \multicolumn{2}{|c|}{ Principle Components } \\
\hline & PC1 & PC 2 \\
\hline Leaf Number & 0.27 & -0.18 \\
\hline Leaf Area & 0.28 & -0.01 \\
\hline Root Length & 0.26 & -0.06 \\
\hline Root Fresh Weight & 0.28 & 0.04 \\
\hline Root Dry Weight & 0.28 & -0.12 \\
\hline Shoot Length & 0.28 & -0.08 \\
\hline Shoot Fresh Weight & 0.28 & 0.01 \\
\hline Shoot Dry Weight & 0.27 & 0.03 \\
\hline SPAD & 0.27 & 0.12 \\
\hline Electrolyte leakage & -0.28 & -0.03 \\
\hline Total phenols (mg GAE/g) & 0.20 & 0.52 \\
\hline Total Flavonoids ( $\mu \mathrm{g} \mathrm{QE} / \mathrm{g})$ & 0.28 & 0.11 \\
\hline DPPH (IC50) & -0.18 & -0.55 \\
\hline CAT ( $\mu \mathrm{Mol} / \mathrm{g} / \mathrm{min})$ & -0.21 & 0.36 \\
\hline $\mathrm{APX}(\mu \mathrm{Mol} / \mathrm{g} / \mathrm{min})$ & -0.21 & 0.45 \\
\hline Eigenvalues & 12.5 & 1.8 \\
\hline$\%$ of variance & 83.6 & 12.3 \\
\hline Cumulative \% & 83.6 & 95.9 \\
\hline
\end{tabular}




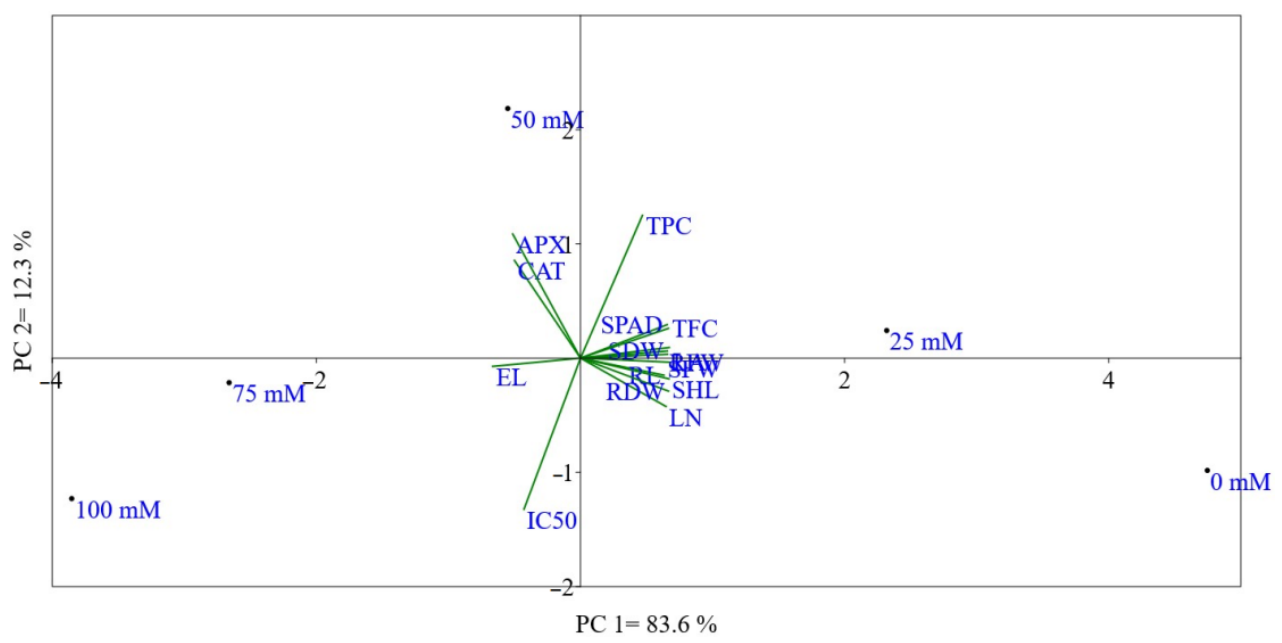

Figure 3. Biplot resulting from PCA procedure for all the variables measured in greenhouse conditions under different $\mathrm{NaCl}$ treatments $(0,25,50,75$, and $100 \mathrm{mM})$. Leaf number (LA), leaf area (LA), root length (RL), root fresh weight (RFW), root dry weight (RDW), shoot length (SHL), shoot fresh weight (SFW), shoot dry weight (SDW), electrolyte leakage (EL), total phenol content (mg $\mathrm{GAE} / \mathrm{g}$ ) (TPC), total flavonoids ( $\mu \mathrm{g} \mathrm{QE} / \mathrm{g})$, catalase ( $\mu \mathrm{Mol} / \mathrm{g} / \mathrm{min})(\mathrm{CAT})$, ascorbic peroxidase $(\mu \mathrm{Mol} / \mathrm{g} / \mathrm{min})(\mathrm{APX})$.

\subsection{Salinity Effect on Metabolite Synthesis}

Thirty-nine metabolites, including essential oils, are differentially expressed in response to $\mathrm{NaCl}$ stress. The GC/MS analysis of hexane extracts of plants grown in vivo revealed significant quantitative changes in the metabolite composition in response to $\mathrm{NaCl}$ treatments (Figure 4). The total number of compounds identified in all the treatments was $22,13,24,9$, and 8 in the control for treatments of $25,50,75$, and $100 \mathrm{mM}$ of NaCl, respectively. These phytochemicals represented 92 (control), $93.7(25 \mathrm{mM}$ of $\mathrm{NaCl}), 95.35$ (50 mM of NaCl), $95.3(75 \mathrm{mM}$ of $\mathrm{NaCl})$, and $91.2 \%(100 \mathrm{mM}$ of $\mathrm{NaCl})$ to $95.35 \%$ of the extracts, and their quantity differed in different treatments.

Among the total metabolites identified in the extract, styrene (11-32\%) and alkanes including decane, dodecane, and tetradecane were detected in more abundant quantities. These compounds have shown carcinogenic activity and are asphyxiants and skin irritants, and thus have adverse health effects [44-46]. The data show that mild salinity stress $(25-75 \mathrm{mM})$ elevated the composition of essential oils benzimidazole, $\beta$ bisabolene, $\beta$-ionone, caryophyllene oxide, hexadecane, methyl oxyphenyl, naphthalene decahydrodimethyl, phytol, propene-1-one, quatephenyl, sesquiphallendren, and triphenyl benzene following a decline at severe stress, indicating the diversity of metabolite responses to various stress levels. An increase in essential oil yield with salinity has been reported previously in sage [47]. Several of the metabolites that increased due to mild salt stress reportedly function as anticancer agents through various molecular mechanisms.

$\beta$-ionone inhibits MDA-MB 435 cells' proliferation by regulating the MAPKs pathway. $\beta$-bisabolene is most commonly used in the treatment of breast cancers [48]. Caryophyllene oxide interferes with multiple signaling cascades involved in tumorigenesis and is used to prevent and treat cancer [49]. A terpenoid, sesquiphellandrene, and heterocyclic organic compound, benzimidazole, demonstrated cytotoxic activity against various cancer cell lines [50]. These derivatives of 1,3-diphenyl-2-propen-1-one, which is a flavonoid precursor, are known to have genotoxic, cytotoxic, antigenotoxic, and anticytotoxic activities [51]. Phytol, a chlorophyll component, is an antiarthritic agent that interacts with key inflammatory pathways of arthritis. Methyloxyphenyl is used as a muscle relaxant, while phytol attenuates inflammatory reactions, decreasing the release of cytokines [52,53]. Naphthalene deca hydro dimethyl is a volatile compound of essential oils most commonly present in flowers exhibiting antifungal properties [54]. 


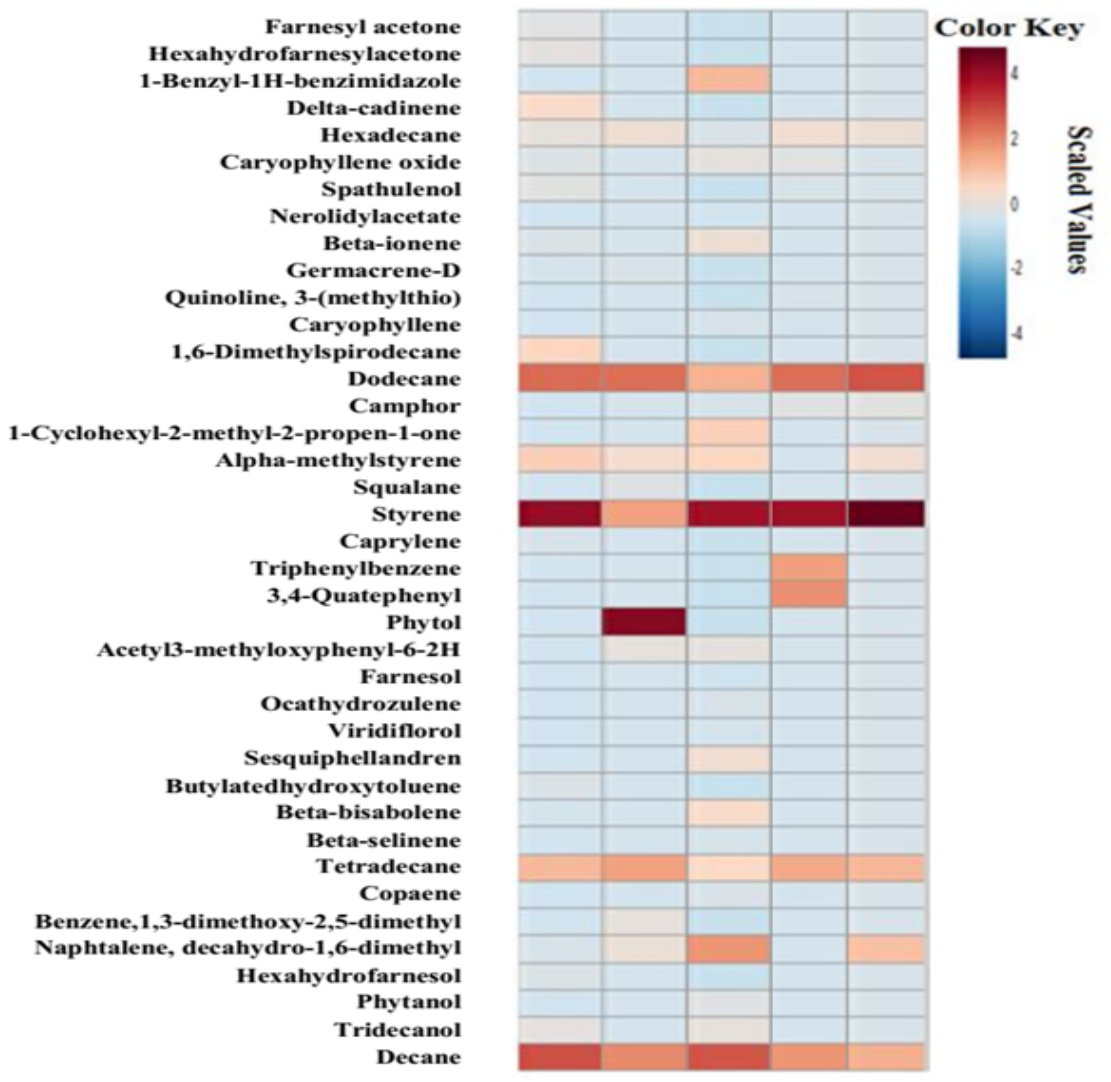

Figure 4. The heat map of detected compounds under different $\mathrm{NaCl}$ concentrations.

Salt stress may also affect the essential oil accumulation indirectly through its effects on either net assimilation or the partitioning of the assimilate among growth and differentiation processes. An excess of sodium (Na) in the cytoplasm inhibits several enzyme activities. It also disrupts potassium absorption, causing a high $\mathrm{Na} / \mathrm{K}$ ratio, reducing plant growth, and increasing oil gland density before leaf emergence [55]. In an experiment performed on Salvia officinalis, cineol had the highest percentage at 50 and $75 \mathrm{mM}$ of salt, and manool had the highest rate at $100 \mathrm{mM}$ [56].

It is noteworthy that in the present studies and published literature, the metabolites of therapeutic value have shown an increase in response to mild salt stress up to $75 \mathrm{mM}$ of $\mathrm{NaCl}$. Furthermore, we observed an increase in the metabolites, triphenyl benzene, quatephenyl, and hexadecane, which are volatile phytotoxic compounds and were found to be soil contaminants [57]. Known antibacterial, antifungal, anti-inflammatory compounds delta cadenine, tridecanol, 1,6, dimethylspirodecane, and alpha-methyl styrene were reduced during salinity stress [58-61]. Salinity levels decreased the essential oil (EO) yield of Rosmarinus officinalis L., where 1,8-cineole content decreases up to $50 \%$ with increasing $\mathrm{NaCl}$ concentrations (from 25 to $200 \mathrm{mM}$ ) [62].

\section{Conclusions}

Salinity stress causes considerable alteration in morphological and physiological characteristics and reduces the cell membrane stability of Ballota nigra. All growth-related traits and SPAD were decreased in vivo and in vitro with increased salinity stress at 50 and $100 \mathrm{mM}$ of $\mathrm{NaCl}$. Total phenolics and flavonoids were reduced in response to salinity stress, while an increase in total flavonoids was observed in vitro cultures in response to $\mathrm{NaCl}$. The increased activity of CAT and APX enzymes in response to moderate and high levels of $\mathrm{NaCl}$ both in vivo and in vitro suggests that the plant is moderately tolerant to 
salt stress. More detailed studies using different cultivars of B. nigra provide additional information on the diversity for salt tolerance available in this important medicinal plant.

The level of salinity stress exhibited a shift and a mixed response in the metabolite composition of the plant extract. An increase in the $\mathrm{NaCl}$ concentration caused a reduction in the total metabolites. Metabolites, styrene, and certain alkanes, which are carcinogenic, were detected in greater abundance and unaffected by salt stress. The expression of delta cadenine, tridecanol, and similar metabolites known for antibacterial properties was observed, and their anti-inflammatory properties were reduced in response to $\mathrm{NaCl}$ treatment. Mild salinity stress elevated metabolites such as $\beta$-ionone and caryophyllene oxide with anticancer activities and other properties. However, at higher stress (>75 mM of $\mathrm{NaCl}$ ), their quantities reduced significantly. Furthermore, the increased levels of these enzymes in cell cultures treated with higher $\mathrm{NaCl}$ concentrations plausibly manipulate cellular biosynthesis for flavonoids in vitro to produce secondary metabolites at moderate to high $\mathrm{NaCl}$ concentrations.

\section{Material and Methods}

\subsection{Plant and Growth, Maintenance, and Salinity Treatment In Vivo}

Seeds of B. nigra were soaked in warm water for $30 \mathrm{~min}$ [63] and sown in soil surface of 70-hole planting trays (five seeds in each hole) containing cocopeat and perlite at a ratio of 1:1, while the seed surface with a thin layer of perlite was covered. To prepare the pot cultivation bed, soil samples were air-dried in a greenhouse, passed through a sieve for uniformity and mixed with an equal amount of completely rotted animal manure. In each pot with a diameter of $20 \mathrm{~cm}$ and a height of $18 \mathrm{~cm}, 3 \mathrm{~kg}$ of prepared dry soil was poured. Finally, the seedlings were transferred to the prepared pots in a four-leaf stage.

Salinity treatments: Sodium chloride treatments were applied at concentrations of 0 , $0.71,1.81,2.9$, and $4 \mathrm{NaCl}$ (g/ $\mathrm{kg}$ of soil). This is equivalent to electrical conductivity (EC) of $2,2.28,4.57,6.85,14.9 \mathrm{dS} / \mathrm{m}$, respectively. To calculate the amount of salt required for $3 \mathrm{~kg}$ of soil in each pot, a given amount of soil was placed in a container, saturated with a sufficient amount of water, and weighed with a precise scale, then placed in an oven at 70 degrees Celsius, and after $24 \mathrm{~h}$, it was weighed again, and the following formula was used to obtain the percentage of soil saturation:

Saturated moisture $\%=($ weight of saturated soil - weight of dry soil $) /($ weight of dry soil $) \times 100 \%$

The percentage of soil moisture saturation indicates the amount of water added to a dry soil until it reached saturation. Various concentrations of sodium chloride were added according to the maximum desired electrical conductivity, and after $24 \mathrm{~h}$, the electrical conductivity was measured. Sodium chloride was applied four times using field capacity at intervals of 4 days, and the plants were irrigated until the harvest.

\subsection{Plant Harvest and Sampling}

The fresh samples were prepared from the leaves and shoots to measure the content of phenolic compounds, flavonoids, chlorophyll, free radical scavenging activity (1,1-Diphenyl-2-picrylhydrazyl-DPPH), catalase (CAT), and ascorbic peroxidase (APX) enzymes. The plant samples were harvested and dried in the dark and stored for further analysis of secondary metabolites.

\subsection{Plant Growth, Maintenance, and Salinity Treatment In Vitro}

The seeds were washed in distilled water for $10 \mathrm{~min}$, followed by soaking in $70 \%$ alcohol for $10 \mathrm{~min}$. Seeds were surface sterilized in 1\% sodium hypochlorite solution $(20 \mathrm{~mL}$ of $5 \%$ standard bleach was diluted with $80 \mathrm{~mL}$ of sterile distilled water) and two drops of dishwashing liquid for 20 min while shaking. The seeds were planted in the jars containing MS basal medium and incubated in the growth chamber.

When the $B$. nigra seedlings had sufficiently grown, their outer surface was sterilized by spraying $70 \%$ ethanol to obtain sterile explants. The explants used included a $1-\mathrm{cm}$ long stem and stem tip so that each piece had one node and leaf. Explants were placed in 
MS medium containing $5 \mu \mathrm{mol}$ of benzylaminopurine (BAP), $1 \mu \mathrm{mol}$ of indole acetic acid (IAA), and different $\mathrm{NaCl}$ concentrations $(0,25,50,75,100 \mathrm{mM}$ of $\mathrm{NaCl})$. After cultivation, the cultures were transferred into a growth chamber with a temperature of $24{ }^{\circ} \mathrm{C}$ under a $16 \mathrm{~h}$ photoperiod. After four weeks, seedling traits were recorded in a culture medium.

\subsection{Measurement of Growth and Morphological Characteristics}

The growth and morphological traits of control and NaCl-treated plants were studied, including root and shoot length $(\mathrm{cm})$, their fresh and dry weight $(\mathrm{g})$, and the number of leaves and leaf area (using T Device $\Delta$ leaf area meter, UK) were recorded in plants cultured in vivo and in vitro. The dry weight was measured after $48 \mathrm{~h}$ of frying the plant material in the air-dry oven at $70^{\circ} \mathrm{C}$.

\subsection{Measurement of Electrolyte Leakage (\%)}

To evaluate the cell membrane stability (CMS) of plants growing in a greenhouse, $10 \mathrm{~mL}$ of double-distilled water was first poured into glass jars. Then, several discs were prepared from two young and developed leaves from the top of the vegetation one week before harvest and placed in the pot. After $24 \mathrm{~h}$ in the dark, each pot's electrical conductivity (E0) was measured by an EC meter. The pots were autoclaved for $20 \mathrm{~min}$, and after cooling, their electrical conductivity was measured as the maximum electrolyte (EC1) output from the leaf. Finally, the following formula was used to calculate the CMS:

$$
\mathrm{CMS} \%=(\mathrm{EC} 0 / \mathrm{EC} 1) \times 100
$$

\subsection{Antioxidant Activity Assay/Radical Scavenging Assay}

In brief, $10 \mu \mathrm{L}$ of the methanol extract of $B$. nigra was added to $1 \mathrm{~mL}$ of $0.004 \%$ methanol solution of DPPH. After $30 \mathrm{~min}$, the remaining DPPH was determined at $517 \mathrm{~nm}$ using a UV-visible spectrophotometer. DPPH inhibition percentage (I\%) was calculated as follows below:

$$
\mathrm{I} \%=[(\text { A control }- \text { A sample }) / \text { A control }] \times 100
$$

where control is the absorbance of control reaction and half-maximal inhibitory concentration (IC50) was considered the concentration of the extracts showing 50\% of inhibition in $\mathrm{DPPH}$, as calculated from the graph, plotting inhibition against different concentrations of extracts.

\subsection{Measurement of Total Flavonoids}

Total amount of flavonoids was measured based on the formation of the flavonoidaluminum complex [64]. The reaction mixture consisted of $1.5 \mathrm{~mL}$ of methanol, $100 \mu \mathrm{L}$ of $2 \%$ methanolic aluminum chloride, $100 \mu \mathrm{L}$ of sodium acetate $(50 \mathrm{~g} / \mathrm{L}), 500 \mu \mathrm{L}$ of extract and incubation at room temperature for $30 \mathrm{~min}$. The absorbance was measured at $415 \mathrm{~nm}$, and the flavonoids were expressed in ug quercetin/g extract.

\subsection{Total Phenol Measurement}

The amount of phenol was determined using the Folin reagent [47]. A total of $20 \mathrm{~g}$ of sodium carbonate was weighed and diluted in $100 \mathrm{~mL}$ of distilled water. The reaction mixture contained $1.5 \mathrm{~mL}$ of methanol, $2 \mathrm{~mL}$ of Folin-Ciocalteu reagent, and $500 \mu \mathrm{L}$ of extract. After $5 \mathrm{~min}, 3.75 \mathrm{~mL}$ of the prepared sodium carbonate solution was added. The resulting reaction mixture was incubated at room temperature for $90 \mathrm{~min}$, and its absorbance was measured at $725 \mathrm{~nm}$. The total phenol content of each sample was expressed in terms of Gallic acid equivalent (GAE) according to the standard.

\subsection{Measurement of Catalase (CAT) and Ascorbic Peroxidase (APX) Activity}

Five hundred $\mathrm{mg}$ of leaf sample was dissolved in $2 \mathrm{~mL}$ of extraction buffer $(50 \mathrm{mM}$ Tris $\mathrm{HCl}$ ) and thoroughly homogenized in a previously cooled mortar. The resulting mixture 
was centrifuged in a tube for $10 \mathrm{~min}$ at 13,000 pm, followed by taking the upper phase to read the activity of the enzymes.

The activity of the CAT enzyme was measured using $20 \mu \mathrm{L}$ of enzyme extract mixed with $980 \mu \mathrm{L}$ of phosphate buffer containing $2 \mathrm{mM}$ of hydrogen peroxide $\left(\mathrm{H}_{2} \mathrm{O}_{2}\right)$. The absorption was measured using a spectrophotometer at $240 \mathrm{~nm}$. Enzymatic activity was calculated using Beer Lambert's law, with a catalase extinction coefficient of $39.4 \mathrm{mM}^{-1} \mathrm{~cm}^{-1}$, and finally expressed in $\mathrm{uM} / \mathrm{gfwt} / \mathrm{min}$. To measure the APX activity, $50 \mu \mathrm{L}$ of the extract was mixed with $1 \mathrm{~mL}$ of measuring solution containing $50 \mathrm{mM}$ of potassium phosphate buffer ( $\mathrm{pH}=7), 0.1 \mathrm{mM}$ of EDTA, $0.5 \mathrm{mM}$ of ascorbic acid, and $0.15 \mathrm{mM}^{\circ} \mathrm{H}_{2} \mathrm{O}_{2}$. Sample absorptions (after $1 \mathrm{~min}$ ) were read with a spectrophotometer at $290 \mathrm{~nm}$. One unit of APX is equivalent to the breakdown of one $\mathrm{mM}$ of ascorbic acid per minute.

\subsection{Identification and Characterization of Metabolites}

The aerial parts of the plant stems and the leaves were dried at room temperature after harvest, powdered with an electric grinder, and mixed with n-hexane solvent, using the maceration method for 7 days with occasional shaking. Finally, the mixture was filtered then centrifuged to discard the solid residues. The extracts were kept in closed containers in the refrigerator until analysis.

The extracts were analyzed by GC-MS using Agilent 7890A Network GC system combined with Agilent 5975C Network with Triple-Axis Detector. GC analysis was equipped with a splitless model injector (with $1.0 \mu \mathrm{m}$ volume and $250{ }^{\circ} \mathrm{C}$ temperature). HP 5MS capillary column $(30 \mathrm{~m} \times 0.25 \mathrm{~mm}$, film thickness $0.25 \mu \mathrm{m})$ was used, and helium served as the carrier gas $(1.1 \mathrm{~mL} / \mathrm{min})$. The column pressure was fixed at 8.13 PSI. Oven temperature was initially kept at $50{ }^{\circ} \mathrm{C}$ for $2 \mathrm{~min}$ after injection and then increased to $250{ }^{\circ} \mathrm{C}$ with an $8{ }^{\circ} \mathrm{C} / \mathrm{min}$ heating ramp and kept constant at $250^{\circ} \mathrm{C}$ for $2 \mathrm{~min}$. A hydrocarbon mixture for retention index (RI) measurement was injected under the above conditions.

MS was performed with an ionization voltage of $70 \mathrm{eV}$ and a mass range of $34-500 \mathrm{~m} / z$. Temperatures of $280^{\circ} \mathrm{C}$ and $250{ }^{\circ} \mathrm{C}$ were used as anion source and interface temperatures, respectively. The retention indices of the compounds were calculated based on the C8-C20 series of alkane.

Identification of essential oil components (Eos):

Constituents of the essential oils (Eos) were identified by matching their retention indices and mass spectra pattern with related available data and/or with the authentic compounds. Additionally, the identification was made by comparing Wiley NBS mass spectral library and literature (NIST Chemistry WebBook) [65,66]. In addition, retention indices of the main constituents were composed of authentic compounds to confirm their precise identification. To quantify the individual components' percentage, each element's peak area was divided by the total peak area of all essential oil compounds.

\subsection{Statistical Analysis}

All in vivo and in vitro experiments were performed in a randomized complete block design with five treatments and three replications. Analysis of variance was performed using statistical software, Ver 22 SPSS, and the mean comparison was performed using Duncan's multiple range test at 0.05 significance level. Principle component analysis (PCA) was applied to evaluate the association between variables measured in greenhouse conditions under different $\mathrm{NaCl}$ treatments. To carry out the PCA procedure, 165 data $(55 \times 3$ repeats) were analyzed, and then the eigenvalues were calculated using a correlation matrix among the variables, and the two-dimensional score and loading plots were created.

Author Contributions: M.Y.-H.: Methodology, data curation, writing original draft; Z.D.: Methodology, data curation, software; S.O.: Conceptualization, formal analysis, validation; T.V.: Formal analysis, investigation, software; R.K.: Formal analysis, funding acquisition, writing editing, reviewing; N.M.: Conceptualization, formal analysis, funding acquisition, supervision, writing editing, reviewing. All authors have read and agreed to the published version of the manuscript. 
Funding: N.M., M.Y.-H., Z.D. and S.O. received fund from the University of Tabriz and T.V. and R.K. were supported by the Grant 1560049 from FAMU NSF REU.

Institutional Review Board Statement: Not applicable.

Informed Consent Statement: Not applicable.

Data Availability Statement: The datasets generated during and/or analyzed during the current study are available from the corresponding authors on reasonable request.

Acknowledgments: N.M., M.Y.-H., Z.D. and S.O. would like to thank the University of Tabriz for supporting and funding the research. T.V. and R.K. acknowledge the support of FAMU NSF REU Grant 1560049 to conduct this research.

Conflicts of Interest: The authors declare no conflict of interest.

\section{References}

1. Flowers, T.J.; Gaur, P.M.; Gowda, C.L.; Krishnamurthy, L.; Samineni, S.; Siddique, K.H.; Colmer, T.D. Salt sensitivity in chickpea. Plant Cell Environ. 2010, 33, 490-509. [CrossRef]

2. Sairam, R.K.; Rao, K.V.; Srivastava, G.C. Differential response of wheat genotypes to long term salinity stress in relation to oxidative stress, antioxidant activity and osmolyte concentration. Plant Sci. 2002, 163, 1037-1046. [CrossRef]

3. Xie, W.; Wu, L.; Zhang, Y.; Wu, T.; Li, X.; Ouyang, Z. Effects of straw application on coastal saline topsoil salinity and wheat yield trend. Soil Tillage Res. 2017, 169, 1-6. [CrossRef]

4. Fathizad, H.; Ardakani, M.A.H.; Sodaiezadeh, H.; Kerry, R.; Taghizadeh-Mehrjardi, R. Investigation of the spatial and temporal variation of soil salinity using random forests in the central desert of Iran. Geoderma 2020, 365, 114233. [CrossRef]

5. Jordanov, D.; Velčev, V.; Kožuharov, S.I. Flora na Narodna Republika Bulgariâ; Izd-vo na Bulgarskata Akademiâ na Naukite: Sofia, Bulgaria, 1982.

6. Sahin, F.P.; Toker, M.C.; Ezer, N. Botanical properties of a Mild Sedative: Ballota nigra L. subsp. nigra. FABAD J. Pharm. Sci. 2005, 30,94 .

7. Kennedy, J. Herb and supplement use in the US adult population. Clin. Ther. 2005, 27, 1847-1858. [CrossRef]

8. Bandaranayake, W.M. Quality Control, Screening, Toxicity, and Regulation of Herbal Drugs. In Modern Phytomedicine. Turning Medicinal Plants into Drugs; Ahmad, I., Aqil, F., Owais, M., Eds.; Wiley-VCH GmbH \& Co. KGa A: Weinheim, Germany, 2007; pp. 25-57.

9. Belaqziz, R.; Romane, A.; Abbad, A. Salt stress effects on germination, growth, and essential oil content of an endemic thyme species in Morocco (Thymus maroccanus Ball.). J. Appl. Sci. Res. 2009, 5, 858-863.

10. Said-Al Ahl, H.A.H.; Omer, E.A. Medicinal and aromatic plants production under salt stress. A review. Herba Polonica 2011, 57, $72-87$.

11. Najafian, S.; Khoshkhui, M.; Tavallali, V.; Saharkhiz, M.J. Effect of salicylic acid and salinity in thyme (Thymus vulgaris L.): Investigation on changes in gas exchange, water relations, and membrane stabilization and biomass accumulation. Aust. J. Basic Appl. Sci. 2009, 3, 2620-2626.

12. Oueslati, S.; Karray-Bouraoui, N.; Attia, H.; Rabhi, M.; Ksouri, R.; Lachaal, M. Physiological and antioxidant responses of Mentha pulegium (Pennyroyal) to salt stress. Acta Physiol. Plant. 2010, 32, 289-296. [CrossRef]

13. Zhu, J.K. Plant salt tolerance. Trends Plant Sci. 2001, 6, 66-71. [CrossRef]

14. Amanifar, S.; Khodabandeloo, M.; Fard, E.M.; Askari, M.S.; Ashrafi, M. Alleviation of salt stress and changes in glycyrrhizin accumulation by arbuscular mycorrhiza in liquorice (Glycyrrhiza glabra) grown under salinity stress. Environ. Exp. Bot. 2019, 160, 25-34. [CrossRef]

15. Farsaraei, S.; Moghaddam, M.; Pirbalouti, G.A. Changes in growth and essential oil composition of sweet basil in response to salinity stress and super absorbents application. Sci. Hortic. 2020, 271, 109465. [CrossRef]

16. Jaiswal, D.; Pandey, A.; Mukherjee, A.; Agrawal, M.; Agrawal, S.B. Alterations in growth, antioxidative defense, and medicinally important compounds of Curcuma caesia Roxb. under elevated ultraviolet-B radiation. Environ. Exp. Bot. 2020, 177, 104152. [CrossRef]

17. Banerjee, A.; Roychoudhury, A. Seed Priming Technology in the Amelioration of Salinity Stress in Plants. In Advances in Seed Priming; Springer: Singapore, 2018; pp. 81-93.

18. Bistgani, E.Z.; Hashemi, M.; DaCosta, M.; Craker, L.; Maggi, F.; Morshedloo, R.M. Effect of salinity stress on the physiological characteristics, phenolic compounds, and antioxidant activity of Thymus vulgaris L. and Thymus daenensis Celak. Ind. Crops Prod. 2019, 135, 311-320. [CrossRef]

19. Chrysargyris, A.; Michailidi, E.; Tzortzakis, N. Physiological and biochemical responses of Lavandula angustifolia to salinity under mineral foliar application. Front. Plant Sci. 2018, 9, 489. [CrossRef] [PubMed]

20. Neffati, M.; Marzouk, B. Changes in essential oil and fatty acid composition in coriander (Coriandrum sativum L.) leaves under saline conditions. Ind. Crops Prod. 2008, 28, 137-142. [CrossRef] 
21. Aziz, E.E.; Al-Amier, H.; Craker, L.E. Influence of salt stress on growth and essential oil production in peppermint, pennyroyal, and apple mint. J. Herbs Spices Med. Plants 2008, 14, 77-87. [CrossRef]

22. Said-Al Ahl, H.A.H.; Meawad, A.A.; Abou-Zeid, E.N.; Ali, M.S. Response of different basil varieties to soil salinity. Int. Agrophys. 2010, 24, 183-188.

23. Gebauer, J.; El-Siddig, K.; Salih, A.A.; Ebert, G. Tamarindus indica L. seedlings are moderately salt tolerant when exposed to NaCl-Induced salinity. Sci. Hortic. 2004, 103, 1-8. [CrossRef]

24. Tavakkoli, E.; Rengasamy, P.; McDonald, G.K. High concentrations of Na+ and Cl-ions in soil solution have simultaneous detrimental effects on growth of faba bean under salinity stress. J. Exp. Bot. 2010, 61, 4449-4459. [CrossRef]

25. Cramer, G.R. Sodium-Calcium Interactions Under Salinity Stress. In Salinity: Environment-Plants-Molecules; Springer: Dordrecht, The Netherlands, 2008; pp. 205-227.

26. Bhatt, R.M.; Rao, N.S. Influence of pod load on the response of okra to water stress. Indian J. Plant Physiol. 2005, 10, 54.

27. Rezgui, M.; Majdoub, N.; Ben-Kaab, S.; Marzouk, B.; Gouia, H.; Araújo, M.E.M.; Ben-Kaab, L.B. How salt stress represses the biosynthesis of marrubiin and disturbs the antioxidant activity of Marrubium vulgare L. Pol. J. Environ. Stud. 2017, 26, 267-277. [CrossRef]

28. Naeem, M.S.; Jin, Z.L.; Wan, G.L.; Liu, D.; Liu, H.B.; Yoneyama, K.; Zhou, W.J. 5-Aminolevulinic acid improves photosynthetic gas exchange capacity and ion uptake under salinity stress in oilseed rape (Brassica napus L.). Plant Soil 2010, 332, 405-415. [CrossRef]

29. Harrathi, J.; Attia, H.; Neffati, M.; Hosni, K.; Marzouk, B.; Lachâal, M.; Karray-Bouraoui, N. Salt effects on shoot growth and essential oil yield and composition in safflower (Carthamus tinctorius L.). J. Essent. Oil Res. 2013, 25, 482-487. [CrossRef]

30. Venkateswarlu, B.; Ramesh, K. Cell membrane stability and biochemical response of cultured cells of groundnut under polyethylene glycol induced water stress. Plant Sci. 1992, 90, 179-185. [CrossRef]

31. Demidchik, V.; Straltsova, D.; Medvedev, S.S.; Pozhvanov, G.A.; Sokolik, A.; Yurin, V. Stress-Induced electrolyte leakage: The role of K+-Permeable channels and involvement in programmed cell death and metabolic adjustment. J. Exp. Bot. 2014, 65, 1259-1270. [CrossRef]

32. Kumar, S.A.; Kumari, P.H.; Jawahar, G.; Prashanth, S.; Suravajhala, P.; Katam, R.; Sivan, P.; Rao, K.S.; Kirti, P.B.; Kishor, P.K. Beyond just being foot soldiers-osmotin like protein (OLP) and chitinase (Chi11) genes act as sentinels to confront salt, drought, and fungal stress tolerance in tomato. Environ. Exp. Bot. 2016, 132, 53-65. [CrossRef]

33. Manian, R.; Anusuya, N.; Siddhuraju, P.; Manian, S. The antioxidant activity and free radical scavenging potential of two different solvent extracts of Camellia sinensis (L.) O. Kuntz, Ficus bengalensis L. and Ficus racemosa L. Food Chem. 2008, 107, 1000-1007. [CrossRef]

34. Makowczynska, J.; Grzegorczyk, K.I.; Wysokinska, H. Antioxidant activity of tissue culture-Raised Ballota nigra L. plants grown ex vitro. Acta Pol. Pharm. 2015, 72, 769-775.

35. Kanatt, S.R.; Chander, R.; Sharma, A. Antioxidant potential of mint (Mentha spicata L.) in radiation-Processed lamb meat. Food Chem. 2007, 100, 451-458. [CrossRef]

36. Zhou, Y.; Tang, N.; Huang, L.; Zhao, Y.; Tang, X.; Wang, K. Effects of Salt Stress on Plant Growth, Antioxidant Capacity, Glandular Trichome Density, and Volatile Exudates of Schizonepeta tenuifolia Briq. Int. J. Mol. Sci. 2018, 19, 252. [CrossRef]

37. Gill, S.S.; Tuteja, N. Reactive oxygen species and antioxidant machinery in abiotic stress tolerance in crop plants. Plant Physiol. Biochem. 2010, 48, 909-930. [CrossRef]

38. Mittler, R. Oxidative stress, antioxidants, and stress tolerance. Trends Plant Sci. 2002, 7, 405-410. [CrossRef]

39. Das, K.; Roychoudhury, A. Reactive oxygen species (ROS) and response of antioxidants as ROS-Scavengers during environmental stress in plants. Front. Environ. Sci. 2014, 2, 53. [CrossRef]

40. Yan, J.; Guan, L.; Sun, Y.; Zhu, Y.; Liu, L.; Lu, R.; Zhang, A. Calcium and ZmCCaMK are involved in brassinosteroid-Induced antioxidant defense in maize leaves. Plant Cell Physiol. 2015, 56, 883-896. [CrossRef]

41. Aghaei, K.; Ehsanpour, A.A.; Komatsu, S. Potato responds to salt stress by increased activity of antioxidant enzymes. J. Integr. Plant Biol. 2009, 51, 1095-1103. [CrossRef]

42. Vafadar, F.; Amooaghaie, R.; Ehsanzadeh, P.; Ghanadian, M. Salinity stress alters ion homeostasis, antioxidant activities, and the production of rosmarinic acid, luteolin, and apigenin in Dracocephalum kotschyi Boiss. Biologia 2020, 75, 2147-2158. [CrossRef]

43. Dvorak, P.; Krasylenko, Y.; Zeiner, A.; Samaj, J.; Takac, T. Signaling toward ROS-Scavenging enzymes in plants. Front. Plant Sci. 2020, 11, 2178.

44. Green, T.; Lee, R.; Toghill, A.; Meadowcroft, S.; Lund, V. FosterThe toxicity of styrene to the nasal epithelium of mice and rats: Studies on the mode of action and relevance to humans. J. Chem. Biol. Interact. 2001, 137, 185-202. [CrossRef]

45. Singh, S.; Singh, J. Percutaneous absorption, biophysical, macroscopic barrier properties of porcine skin exposed to major components of JP-8 jet fuel. Environ. Toxicol. Pharm. 2003, 14, 77-85. [CrossRef]

46. Yang, J.H.; Lee, C.H.; Monteiro-Riviere, N.A.; Riviere, J.E.; Tsang, C.; Chou, C. Toxicity of jet fuel aliphatic and aromatic hydrocarbon mixtures on human epidermal keratinocytes: Evaluation based on in vitro cytotoxicity and interleukin-8 release. Arch Toxicol. 2006, 80, 508-523. [CrossRef]

47. Khadhri, A.; Neffati, M.; Smiti, S.; Nogueira, J.M.F.; Araújo, M.E.M. Influence of salt stress on essential oil yield and composition of lemon grass (Cymbopogon schoenanthus L. Spreng. ssp. Laniger (Hook) Maire et Weil). Nat. Prod. Res. 2011, 25, 108-117. [CrossRef] 
48. Yeo, S.K.; Ali, A.Y.; Hayward, O.A.; Turnham, D.; Jackson, T.; Bowen, I.D.; Clarkson, R. $\beta$-Bisabolene, a Sesquiterpene from the Essential Oil Extract of Opoponax (Commiphora guidottii), Exhibits Cytotoxicity in Breast Cancer Cell Lines. Phytother. Res. 2016, 30, 418-425. [CrossRef]

49. Park, K.R.; Nam, D.; Yun, H.M.; Lee, S.G.; Jang, H.J.; Sethi, G.; Cho, S.K.; Ahn, K.S. $\beta$-Caryophyllene oxide inhibits growth and induces apoptosis through the suppression of PI3K/AKT/mTOR/S6K1 pathways and ROS-mediated MAPKs activation. Cancer Lett. 2011, 312, 178-188. [CrossRef]

50. Shin, Y.; Lee, Y. Enhanced biodegradation of n-Hexadecane in solid-Phase of soil by employing immobilized Pseudomonas aeruginosa on size-Optimized coconut fibers. Toxicol Res. 2013, 29, 257-261. [CrossRef]

51. Lemes, S.R.; Ribeiro e Silva, C.; Jefferson, H.V.; Chen-Chen, L.; Silva Lima, R.; Caridad, N.P.; Montes de Sousa, M.A.; de Melo Reis, P.R.; da Silva, N.J. Presence of antigenotoxic and anticytotoxic effects of the chalcone 1E,4E-1-(4-Chlorophenyl)-5(2,6,6-Trimethylcyclohexen-1-Yl)Penta-1,4-Dien-3-One using in vitro and in vivo assays. Drug Chem. Toxicol. 2020, 43, 383-390. [CrossRef]

52. Rivero-Cruz, B.; Rojas, M.A.; Rodríguez-Sotres, R.; Cerda-García-Rojas, C.M.; Mata, R. Smooth muscle relaxant action of benzyl benzoates and salicylic acid derivatives from Brickellia veronicaefolia on isolated guinea-pig ileum. Planta Med. 2005, 71, 320-325. [CrossRef]

53. Alexandra, T.; Marina, I.M.; Daniela, M.; Ioana, S.I.; Maria, B.; Radu, R.; Maria, T.A.; Tudor, S.; Maria, G. Autophagy-A Hidden but Important Actor on Oral Cancer Scene. Int. J. Mol. Sci. 2020, 21, 9325. [CrossRef] [PubMed]

54. Hu, X.; Sui, X.; Wang, Y.; Wang, W.; Haibo, W.; Zhang, F.; Yuna, T.; Feng, Z. Sesquiterpene-Neolignans from Manglietia hookeri. Nat. Prod. Res. 2016, 30, 1477-1483. [CrossRef]

55. Said-Al Ahl, H.A.; Abou-Ellail, M.; Omer, E.A. Harvest date and genotype influences growth characters and essential oil production and composition of Petroselinum crispum plants. J. Chem. Pharm. Res. 2016, 8, 992-1003.

56. Taarit, M.B.; Msaada, K.; Hosni, K.; Hammami, M.; Kchouk, M.E.; Marzouk, B. Plant growth, essential oil yield, and composition of sage (Salvia officinalis L.) fruits cultivated under salt stress conditions. Ind. Crops Prod. 2009, 30, 333-337. [CrossRef]

57. Hajieghrari, M.; Hejazi, P. Analysis of heartsease (Viola tricolor L.) flavonoid glycosides by micro-Liquid chromatography coupled to multistage mass spectrometry. J. Hazard. Mater. 2020, 389, 122134. [CrossRef]

58. Akter, K.; Barnes, E.C.; Loa-Kum-Cheung, W.L.; Yin, P.; Kichu, M.; Brophy, J.J.; Barrow, R.A.; Imchen, I.; Vemulpad, S.R.; Jamie, J.F. Antimicrobial and antioxidant activity and chemical characterization of Erythrina stricta Roxb. (Fabaceae). J. Ethnopharmacol. 2016, 185, 171-181. [CrossRef]

59. Pavithra, P.S.; Sreevidya, N.; Verma, R.S. Antibacterial activity and chemical composition of essential oil of Pamburus missionis. J. Ethnopharmacol. 2009, 124, 151-153. [CrossRef]

60. Yin, X.; Liu, Y.; Pan, J.; Ye, H.L.; Sun, Y.; Zhao, D.Y.; Kuang, H.X.; Yang, B.Y. Melongenaterpenes A-L, Vetispirane-Type Sesquiterpenoids from the Roots of Solanum melongena. J. Nat. Prod. 2019, 82, 3242-3248. [CrossRef]

61. Vukic, M.D.; Vukovic, N.L.; Djelic, G.T.; Obradovic, A.; Kacaniova, M.M.; Markovic, S.; Popović, S.; Baskić, D. Phytochemical analysis, antioxidant, antibacterial and cytotoxic activity of different plant organs of Eryngium serbicum L. Ind. Crops Prod. 2018, 115, 88-97. [CrossRef]

62. Tounekti, T.; Khemira, $\mathrm{H} . \mathrm{NaCl}$ stress-Induced changes in the essential oil quality and abietane diterpene yield and composition in common sage. J. Intercult. Ethnopharmacol. 2015, 4, 208-216. [CrossRef] [PubMed]

63. Tung, L.D.; Serrano, E.P. Effects of warm water in breaking dormancy of rice seed. Omonrice 2011, 18, 129-136.

64. Huang, D.J.; Chun-Der, L.I.N.; Hsien-Jung, C.H.E.N.; Yaw-Huei, L.I.N. Antioxidant and antiproliferative activities of sweet potato (Ipomoea batatas [L.] LamTainong 57') constituents. Bot. Bull. Acad. Sin. 2004, 45, 179-186.

65. Adams, R.P. Identification of Essential Oil Components by Gas Chromatography/Mass Spectrometry; Allured Publishing Corporation: Carol Stream, IL, USA, 2017; Volume 456.

66. Linstrom, P.J.; Mallard, W.G. The NIST Chemistry WebBook: A chemical data resource on the internet. J. Chem. Eng. Data 2001, 46, 1059-1063. [CrossRef] 